\title{
Abnormalities of the NMDA Receptor and Associated Intracellular Molecules in the Thalamus in Schizophrenia and Bipolar Disorder
}

\author{
Sarah M Clinton*,' and James H Meador-Woodruff' \\ 'Department of Psychiatry, Mental Health Research Institute, University of Michigan Medical School, Ann Arbor, MI, USA
}

\begin{abstract}
Several lines of investigation support a hypothesis of glutamatergic dysfunction in schizophrenia, including our recent reports of altered NMDA receptor subunit and associated intracellular protein transcripts in the thalamus of elderly patients with schizophrenia. In the present study, we used in situ hybridization to measure the expression of NMDA subunits (NRI, NR2A-D), and associated intracellular proteins (NF-L, PSD95, and SAPI02) in a second, younger cohort from the Stanley Foundation Neuropathology Consortium, which included patients with both schizophrenia and affective disorders. We wanted to determine whether glutamatergic abnormalities in the thalamus in schizophrenia are present at younger ages, and whether these abnormalities occur in other psychiatric illnesses. In the present work, we observed increased expression of NMDA NR2B subunit transcripts, and decreased expression of all three associated postsynaptic density protein transcripts in schizophrenia. We also found evidence of glutamatergic dysfunction in the thalamus in affective disorders, particularly in bipolar disorder. In particular, we found decreased NF-L, PSD95, and SAPI02 transcripts in bipolar disorder, and decreased SAPIO2 levels in major depression. Interestingly, one of the most consistent findings across diagnostic groups was an abnormality of intracellular signaling molecules that are linked to the NMDA receptor, rather than changes in the receptor subunits themselves. PSD95 and similar scaffolding molecules link the NMDA receptor with intracellular enzymes that mediate signaling, and also provide a physical link between different neurotransmitter systems to coordinate and integrate information from multiple effector systems. Abnormalities of PSD95-like molecules and other intracellular signaling machinery may contribute to dysregulated communication between multiple neurotransmitter systems (such as glutamatergic and dopaminergic systems) that are potentially involved in the neurobiology of schizophrenia and affective disorders.

Neuropsychopharmacology (2004) 29, | 353-1362, advance online publication, 3 I March 2004; doi: I0.1038/sj.npp. I30045 I
\end{abstract}

Keywords: glutamate; PSD95; SAPI02; NF-L; mediodorsal nucleus

\section{INTRODUCTION}

The thalamus is composed of numerous topographically organized nuclei that reciprocally project to limbic, sensory, and motor regions of the cerebral cortex. While the thalamus has traditionally been considered a simple relay station, it plays a substantial role in processing and integrating incoming sensory information by not only transmitting information to the cortex but also regulating the ability of the cortex to process this information (Jones, 1998). Numerous post-mortem and in vivo imaging studies report structural (Andreasen et al, 1994; Buchsbaum et al, 1996; Byne et al, 2001; Gilbert et al, 2001; Pakkenberg, 1990;

\footnotetext{
*Correspondence: SM Clinton, Department of Psychiatry, Mental Health Research Institute, University of Michigan, 205 Zina Pitcher Place, Ann Arbor, MI 48109-0720, USA, Tel: + I 734936 206I, Fax: + | 734647 4I30, E-mail: clintons@umich.edu

Received 16 October 2003; revised II January 2004; accepted 18 February 2004

Online publication: I March 2004 at http://www.acnp.org/citations/ Npp030 I0403473/default.pdf
}

Popken et al, 2000) and functional (Hazlett et al, 1999; Silbersweig et al, 1995; Tamminga et al, 1992) abnormalities of the thalamus in schizophrenia, including reduced thalamic cell number and volume, and decreased metabolism (for a review of these findings see Clinton and MeadorWoodruff, 2003). Despite mounting evidence for structural pathology and thalamic dysfunction in schizophrenia, relatively few studies have examined the neurochemical substrates that may accompany these changes (Clinton et al, 2003; Ibrahim et al, 2000b; Oke and Adams, 1987; Smith et al, 2001a,b).

Thalamocortical projections, corticothalamic projections, and sensory afferents to the dorsal thalamus primarily use glutamate as a neurotransmitter, which activates both ionotropic and metabotropic glutamate receptors expressed throughout the thalamus (Ibrahim et al, 2000a; Jones et al, 1998). Several lines of investigation implicate glutamatergic dysfunction in schizophrenia (Coyle, 1996; Goff and Wine, 1997; Olney et al, 1999). The glutamate hypothesis of schizophrenia is based largely on the observation that NMDA receptor antagonists like phencyclidine can trigger a 
schizophrenia-like syndrome in healthy subjects, and exacerbate symptoms in schizophrenia (Lahti et al, 1995). Post-mortem studies have revealed NMDA receptor abnormalities in several limbic structures implicated in schizophrenia, including the prefrontal cortex (Dracheva et al, 2001), hippocampus (Gao et al, 2000), and thalamus (Ibrahim et al, 2000b). Further, clinical trials have shown that treating patients with a combination of standard neuroleptics and drugs that promote NMDA receptor function, such as D-cycloserine, an agonist of the glycine/ D-serine co-agonist site of the NMDA receptor, significantly improve negative symptoms (Goff et al, 1999, 1995; Goff and Coyle 2001; Javitt et al, 1994). Taken together, these data suggest that glutamate, specifically NMDA receptor-mediated, transmission, may be disrupted in schizophrenia.

Glutamate transmission involves myriad molecules, including pre- and postsynaptic receptors and receptorassociated intracellular molecules that link glutamate receptors to signal transduction pathways. The NMDA receptor is a ligand-gated ion channel formed by several subunits, including the obligate NR1 subunit, and combinations of NR2 subunits A-D (Hollmann and Heinemann, 1994). The NR3A and NR3B genes have also been identified, but these subunits are primarily expressed in the brain during development (Das et al, 1998), and in the spinal cord (Chatterton et al, 2002), respectively. Over the last decade, yeast two-hybrid experiments have identified several glutamate receptor-interacting proteins enriched in the postsynaptic density (PSD), which modulate receptor activity and participate in signal transduction pathways. PSD95, the prototype of this family, contains several domains that bind the C-termini of NMDA NR2 subunits in addition to cytoskeletal elements and signal transduction enzymes. These protein-protein interactions facilitate NMDA receptor function by clustering and anchoring the receptor at the $\mathrm{PSD}$, modulating NMDA receptor sensitivity to glutamate, and, perhaps most importantly, assembling a signaling complex to coordinate NMDA receptor-regulated intracellular processes (Sheng, 2001; Sheng and Pak, 2000). Considering the complexity of the glutamate system, it is possible that glutamate dysfunction in schizophrenia may not involve abnormalities of the NMDA receptor, but instead may be due to a disruption of other molecules involved in glutamate neurotransmission (Clinton et al, 2003).

We have recently reported glutamatergic abnormalities in the thalamus of elderly patients with schizophrenia, including decreased expression of NR1 subunit transcripts, decreased binding to the polyamine and glycine sites of the NMDA receptor (Ibrahim et al, 2000b), and increased expression of PSD95-like molecules (Clinton et al, 2003). These data support a hypothesis of glutamatergic dysfunction in the illness, and indicate that these abnormalities not only involve receptors, but also glutamate receptor-related signal transduction pathways. In the present study, we have repeated these experiments in a second, younger cohort from the Stanley Foundation Neuropathology Consortium, which included patients with both schizophrenia and affective disorders. We wanted to determine whether glutamatergic abnormalities in the thalamus are present at earlier ages in schizophrenia, and whether these abnormalities occur in other psychiatric illnesses.

\section{METHODS}

A total of 60 subjects from the Stanley Foundation Neuropathology Consortium were used in these studies. This set consists of 15 patients with schizophrenia, 15 patients with major depressive disorder, 15 patients with bipolar disorder, and 15 nonpsychiatrically ill individuals. A detailed description of this collection has been published (Torrey et al, 2000), and a summary of subject characteristics is shown in Table 1 . Cryostat sectioned $(14 \mu \mathrm{m})$ slides were provided to us and stored at $-80^{\circ} \mathrm{C}$ until use. Two slides per subject were prepared for in situ hybridization for each probe. Measurements were made after the subject code was broken for analysis of earlier samples received by our lab, so data analysis in this particular study was 'unblinded'.

\section{In situ Hybridization}

Riboprobes were synthesized from linearized plasmid DNA containing subclones of NMDA receptor subunits NR1, NR2A-D, and NMDA-associated PSD proteins neurofilament light-chain (NF-L), PSD95, and synapse-associated protein 102 (SAP102), as previously described (Clinton and Meador-Woodruff, 2002; Ibrahim et al, 2000b). Briefly, $100 \mu \mathrm{Ci}$ of $\left[{ }^{35} \mathrm{~S}\right] \mathrm{UTP}$ (New England Nuclear, Boston, MA) was vacuum dried and $2.0 \mu \mathrm{l} 5 \times$ transcription buffer, $1.0 \mu \mathrm{l}$ 0.1 DTT, $1.0 \mu \mathrm{l}$ each of $10 \mathrm{mM}$ ATP, CTP, and GTP, $2.0 \mu \mathrm{l}$ plasmid DNA, $0.5 \mu$ l RNAse inhibitor, and $1.5 \mu \mathrm{l} \mathrm{SP6,} \mathrm{T7,} \mathrm{or}$ T3 RNA polymerase were added and incubated for $2 \mathrm{~h}$ at $37^{\circ} \mathrm{C}$. A measusre of $1 \mu \mathrm{l}$ DNAse (RNAse free) was added to the reaction and incubated for $15 \mathrm{~min}$ at room temperature. The labeled probe was purified using a Micro Bio-Spin P-30 Tris Spin Column (Bio-Rad Laboratories).

Table I Summary of Subject Characteristics

\begin{tabular}{|c|c|c|c|c|}
\hline & Schizophrenia & Bipolar disorder & Major depression & Normal controls \\
\hline$N$ & 15 & 15 & 15 & 15 \\
\hline Age (years) & $44.2(25-62)$ & $42.3(25-61)$ & $46.4(30-65)$ & $48.1(29-68)$ \\
\hline Sex & $9 M, 6 F$ & $9 M, 6 F$ & $9 M, 6 F$ & $9 M, 6 F$ \\
\hline PMI (h) & $33.7(|2-6|)$ & $32.5(13-62)$ & $27.5(7-47)$ & $23.7(8-42)$ \\
\hline Tissue $(\mathrm{pH})$ & $6.1(5.8-6.6)$ & $6.2(5.8-6.5)$ & $6.2(5.6-6.5)$ & $6.3(5.8-6.6)$ \\
\hline Side of brain studied & 6R, 9L & 8R, 7L & 6R, 9L & $7 \mathrm{R}, 8 \mathrm{~L}$ \\
\hline
\end{tabular}

Neuropsychopharmacology 
Two slides per subject were placed in $4 \%$ fomaldehyde at room temperature for $1 \mathrm{~h}$. The slides were then washed in $2 \times \operatorname{SSC}(300 \mathrm{mM} \mathrm{NaCl} / 30 \mathrm{mM}$ sodium citrate, $\mathrm{pH} 7.2)$ three times for $5 \mathrm{~min}$ each. Next, the slides were placed in $0.1 \mathrm{M}$ triethanolamine, $\mathrm{pH}$ 8.0/acetic anhydride, 400:1 (vol:vol), on a stir plate for $10 \mathrm{~min}$. The final wash was in $2 \times \mathrm{SSC}$ buffer $5 \mathrm{~min}$, followed by dehydration through graded ethanol washes and air-drying. A coverslip with $500 \mu \mathrm{l}$ of riboprobe (1 million cpm)/50\% formamide buffer $/ 0.01 \mathrm{M}$ DTT was placed on each slide. Slides were placed in a covered tray lined with filter paper saturated with $50 \%$ formamide buffer and incubated at $55^{\circ} \mathrm{C}$ overnight. Approximately $18 \mathrm{~h}$ later coverslips were removed and the slides in the NR1, NR2A-D, NF-L, and SAP102 studies were washed in $2 \times$ SSC at room temperature for $10 \mathrm{~min}$, and incubated in RNaseA $(200 \mathrm{mg} / \mathrm{ml}$ in $10 \mathrm{mM}$ Tris- $\mathrm{HCl}, \mathrm{pH}$ $8.0 / 0.5 \mathrm{M} \mathrm{NaCl}$ ) at $37^{\circ} \mathrm{C}$ for $30 \mathrm{~min}$. The slides then underwent a series of washes: $2 \times$ SSC for $10 \mathrm{~min} ; 1 \times$ SSC for $10 \mathrm{~min}$ at room temperature; $0.5 \times \mathrm{SSC}$ at $55^{\circ} \mathrm{C}$ for $60 \mathrm{~min}$; and $0.5 \times \mathrm{SSC}$ for $10 \mathrm{~min}$ at room temperature. The slides for the PSD95 studies required different washing conditions. These slides were placed in $2 \times$ SSC at room temperature for $15 \mathrm{~min}$, and then incubated in RNaseA $(200 \mathrm{mg} / \mathrm{ml}$ in $10 \mathrm{mM}$ Tris- $\mathrm{HCl}, \mathrm{pH} 8.0 / 0.5 \mathrm{M} \mathrm{NaCl})$ at $37^{\circ} \mathrm{C}$ for $30 \mathrm{~min}$. Then slides were washed twice in $2 \times$ SSC for $15 \mathrm{~min}$; once in $1 \times \mathrm{SSC}$ for $15 \mathrm{~min}$ at room temperature; twice in $0.5 \times \mathrm{SSC}$ at $55^{\circ} \mathrm{C}$ for $60 \mathrm{~min}$ each; and once in $0.5 \times$ SSC for $15 \mathrm{~min}$ at room temperature. Finally, all of the slides were dehydrated in graded ethanol washes, air-dried, and apposed to film (Kodak Biomax MR-1, New England, Nuclear, Boston, MA) for 5-60 days. For each probe, slides from all subjects were processed together to eliminate interassay variability.

\section{Image and Data Analysis}

Images were acquired from digitized X-ray films and analyzed using Scion Image Beta $3 \mathrm{~b}$ for PC. We identified seven discrete thalamic nuclei in each section: anterior $(\mathrm{A})$, central medial (CM), dorsomedial (DM), ventral anterior (VA), ventral lateral (VL), ventral medial (VM), and the reticular nucleus $(\mathrm{R})$. The nuclei were identified based on cellular and white matter patterns defined by cresyl violet staining of sections from each subject, as we have previously described (Clinton et al, 2003; Ibrahim et al, 2000b). For all experiments, tissue background values from adjacent white matter were subtracted from grayscale values for each nucleus and converted to optical density. The amount of radioactivity bound (in $\mathrm{nCi} / \mathrm{g}$ ) was determined using $\left[{ }^{14} \mathrm{C}\right]$ microscale standards (Amersham Biosciences, Piscataway, NJ) (Miller, 1991), which were exposed on the same film as the slides for each study. The number of labeled uridine nucleotides contained in each riboprobe and the specific activity of the $\left[{ }^{35} \mathrm{~S}\right] \mathrm{UTP}$ were then used to convert bound radioactivity to concentration of mRNA per nucleus, expressed as fmol/g. For all studies, values for each nucleus from two sections per subject were averaged and used for statistical analysis, which was performed for each probe by two-way analysis of variance (ANOVA), with nucleus and diagnosis as independent variables, and mRNA concentrations of each probe as the dependent variable. Post hoc analyses were performed using the Neuman-Keuls test. The
Kolmogorov-Smirnov test was used to ensure normality of all data. Pearson product moment correlations were used to determine relationships between continuously distributed variables. For all tests $\alpha=0.05$.

\section{RESULTS}

\section{NMDA Subunit Expression in Schizophrenia and Affective Disorders}

Transcripts encoding the NMDA subunits NR1, NR2A-D were present in all nuclei studied. They were, however, predominately expressed in the dorsal thalamus, with very low levels present in the reticular nucleus. NR1 transcripts were abundantly expressed throughout the thalamus. NR2B transcripts were also relatively abundant, with moderate levels of NR2A, and low levels of NR2C and NR2D transcripts (Figures 1 and 2). There was a main effect on diagnosis for NR2B mRNA levels $(\mathrm{F}=3.97, \mathrm{df}=3,392$; $p=0.008$ ) (Figure 2). Post hoc analysis showed that this effect was due to a $30 \%$ increase of NR2B transcript expression in the thalamus in schizophrenia. NR2B levels were not significantly altered in either affective disorder compared to controls (Figure 2). There was no main effect on diagnosis for NMDA receptor subunits NR1, NR2A, and $2 \mathrm{D}$, and there were no significant diagnosis $\times$ nucleus interactions for any of the NMDA receptor subunits. Correlational analysis showed that NMDA receptor subunit transcript levels did not correlate significantly with age (correlation coefficients ranged from -0.14 to 0.21 , $p$-values $=0.09-0.97)$. NR2C transcript levels were significantly correlated with post-mortem interval (PMI) $(r=0.41$, $p=0.001)$. PMI for the schizophrenia group is significantly higher than that of the control group, and our ANOVA for NR2C showed a main effect for NR2C, suggesting that NR2C expression was increased in the thalamus of patients with schizophrenia; however, when we included PMI as a covariate in a subsequent analysis, the effect of diagnosis
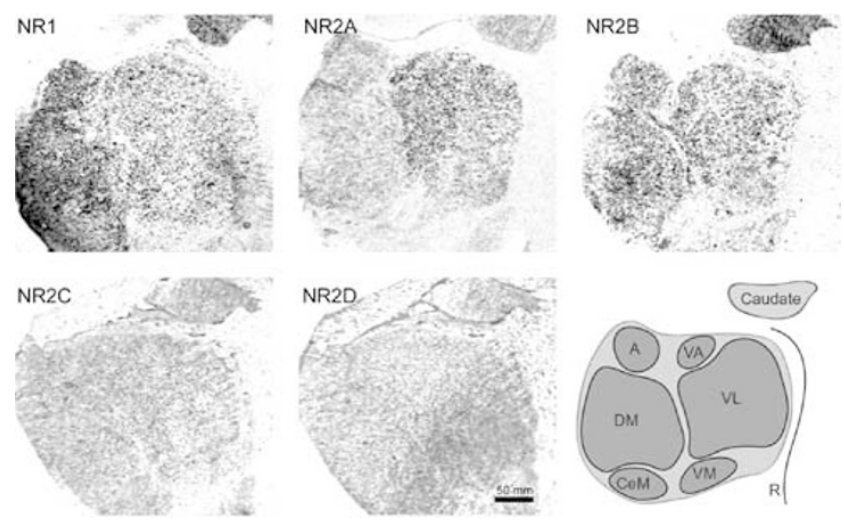

Figure I Transcript expression of NMDA receptor subunits NRI, NR2A-D in the human thalamus. NRI transcripts were heavily expressed across the thalamus. There were also fairly high levels of NR2B transcripts, moderate levels of NR2A, and very low levels of NR2C and NR2D transcripts. In each section, the following nuclei were identified for each subject: anterior (A); central medial (CM); dorsomedial (DM); ventral anterior (VA); ventral lateral (VL); ventral medial (VM), and the reticular nucleus $(R)$. The tail of the caudate nucleus is also readily apparent at this level. 


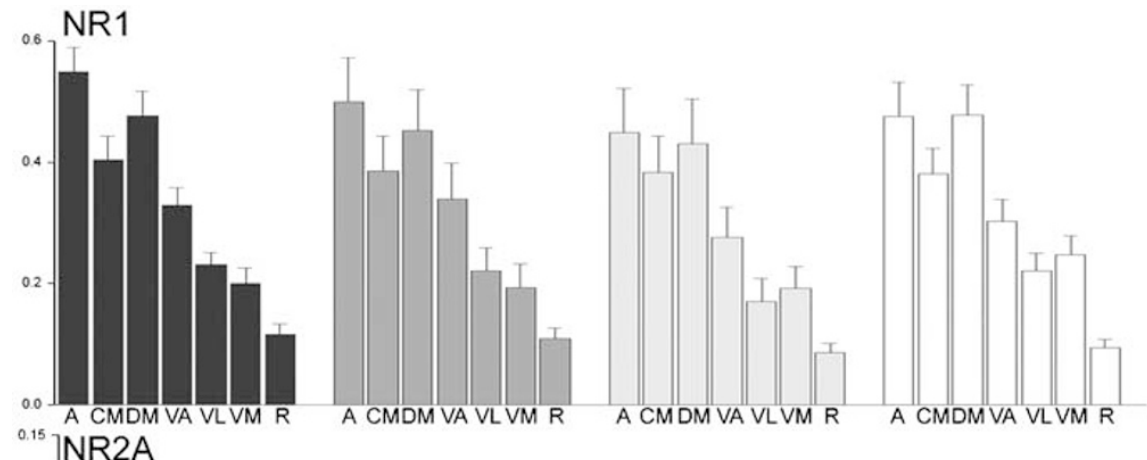

${ }^{0.15}$ NR2A

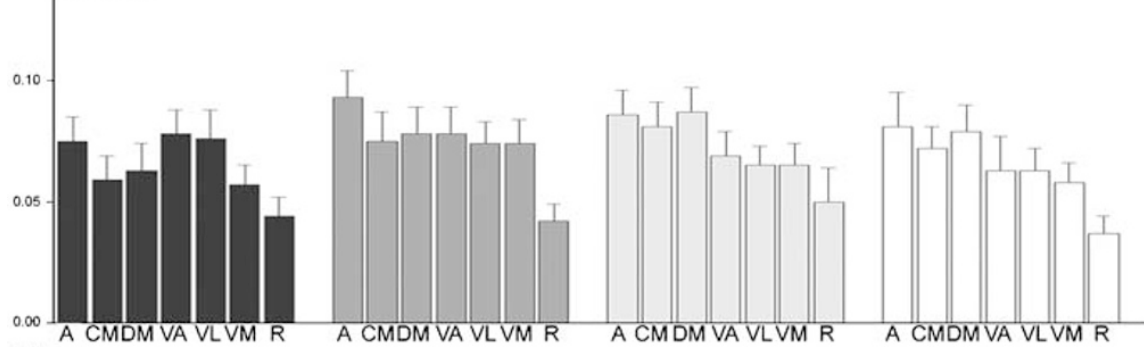

${ }^{024}$ NR2B *

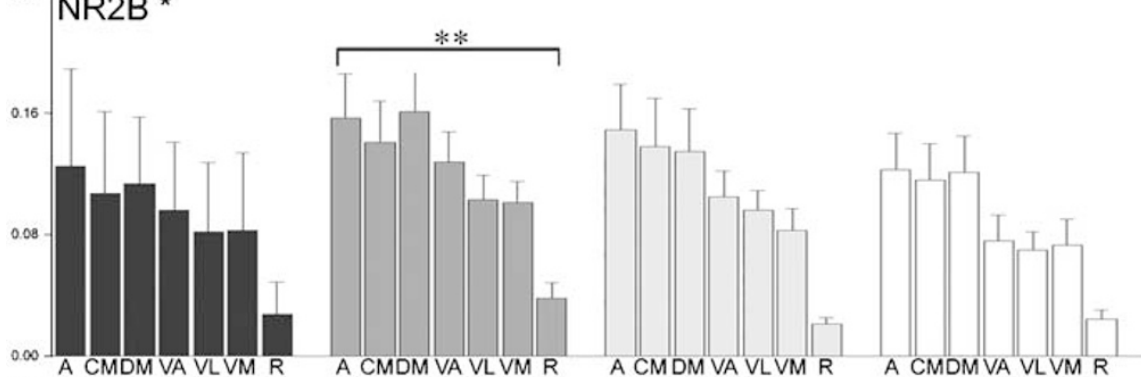

${ }^{0.08} 7 \mathrm{NR} 2 \mathrm{C}$

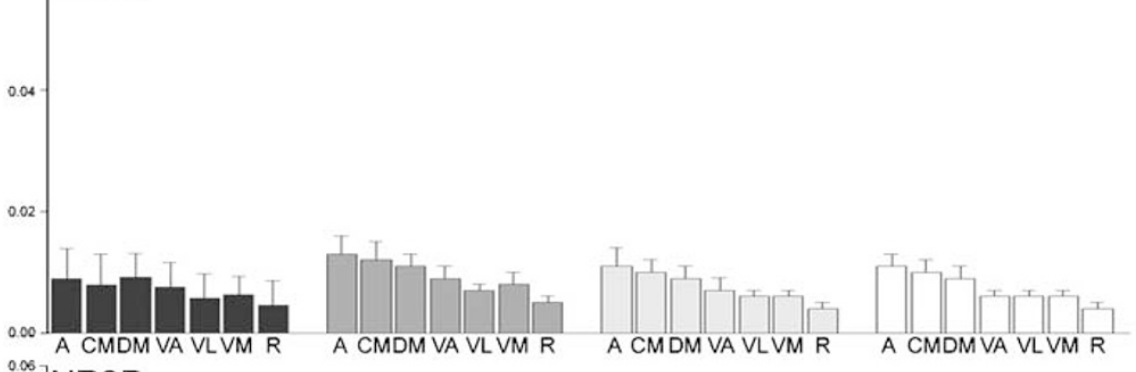

${ }^{0.06}$ NR2D

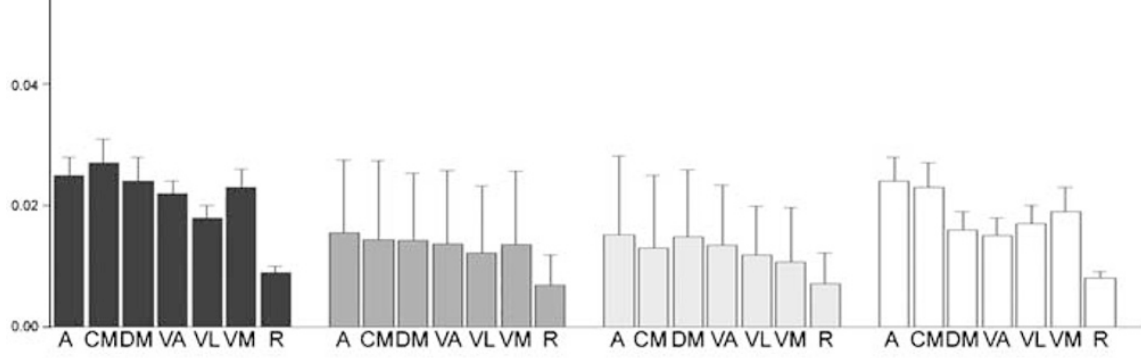

\section{Control}

\section{Schizophrenia}

Bipolar

Depression

Figure 2 Expression of NMDA receptor subunit transcripts in the thalamus in schizophrenia, bipolar illness, and major depression. NMDA receptor subunit transcripts were measured in seven thalamic nuclei: anterior (A); central medial (CM); dorsomedial (DM); ventral anterior (VA); ventral lateral (VL); ventral medial $(V M)$, and the reticular nucleus $(R)$. Values are mean \pm SEM. *Main effect for diagnosis $(p<0.0 \mathrm{I})$ by two-way ANOVA. ***Post hoc analysis indicated that NR2B transcript expression was significantly increased in schizophrenia. 
on NR2C expression was no longer significant. None of the other NMDA subunit transcripts (NR1, NR2A, NR2B, NR2D) correlated with PMI (correlation coefficients ranged from 0.03 to $0.11, p$-values $=0.37-0.75)$. NR1 transcript levels correlated with $\mathrm{pH}(r=0.54, p=0.000009)$, but the other NMDA receptor subunit transcripts did not (correlation coefficients ranged from 0.01 to 0.18 , $p$-values $=0.27-$ 0.84). ANOVA analysis showed that $\mathrm{pH}$ levels were not significantly different between diagnostic groups.

\section{NMDA Receptor-Associated PSD Protein Transcripts in Schizophrenia and Affective Disorders}

NF-L, PSD95, and SAP102 transcripts were expressed in all nuclei studied. NF-L transcripts were abundantly expressed throughout the thalamus. PSD95 transcripts were also abundant, and SAP102 transcripts were moderately expressed in the thalamus (Figures 3 and 4). There was a main effect for diagnosis on NF-L transcript expression ( $F=7.95$, $\mathrm{df}=3,392 ; p=0.00004)$. Post hoc analysis showed that this effect was due to a $29 \%$ decrease of NF-L transcripts in the thalamus of bipolar patients and a $19 \%$ decrease in schizophrenia patients, while levels were unchanged in the depression group (Figure 4). There was a main effect for diagnosis on PSD95 mRNA expression $(\mathrm{F}=4.27, \mathrm{df}=3,392$; $p=0.006)$, which was due to a 24 and $19 \%$ reduction of transcripts in the thalamus of bipolar and schizophrenia patients, respectively (Figure 4). There was also a main effect for diagnosis on SAP102 transcript expression $(\mathrm{F}=5.08, \mathrm{df}=3,392 ; p=0.002)$. Post hoc analysis indicated that this effect was due to 29,29 , and $14 \%$ reductions of SAP102 transcripts in bipolar disorder, schizophrenia, and depression, respectively (Figure 4). There were no significant diagnosis $\times$ nucleus interactions for any of the NMDA receptor-associated PSD proteins. Correlational analysis showed that PSD protein transcripts did not correlate significantly with either age (correlation coefficients ranged from -0.05 to $0.04, p$-values $=0.36-0.69$ ) or PMI (correlation coefficients ranged from -0.19 to -0.07 , $p$-values $=0.13-0.55)$. All of the PSD protein transcripts did, however, correlate with pH: NF-L $(r=0.39, p=0.002)$, PSD95 $(r=0.44, p=0.0004)$, and SAP102 $(r=0.41$, $p=0.001)$. In general, $\mathrm{pH}$ levels are known to influence mRNA quality and stability, and our results are consistent with this notion since the expression of some transcripts is positively correlated with $\mathrm{pH}$. As mentioned above, ANOVA analysis showed that $\mathrm{pH}$ levels were not significantly different between diagnostic groups.
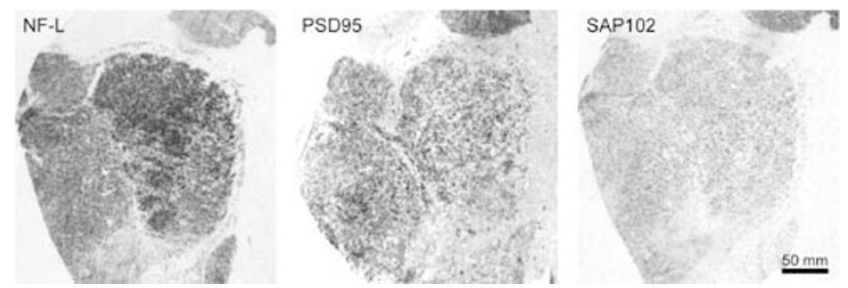

Figure 3 Transcript expression of NMDA receptor-associated PSD proteins NF-L, PSD95, and SAPI02 in the human thalamus. NF-L transcripts were abundantly expressed throughout the thalamus. PSD95 transcripts were also heavily expressed in the thalamus, with moderate levels of SAPI02 transcripts expression.

\section{DISCUSSION}

We have previously reported abnormalities of NMDA receptors and associated intracellular proteins in the thalamus of elderly patients with schizophrenia (Clinton et al, 2003; Ibrahim et al, 2000b). In the present studies we have again observed changes in the expression of some NMDA receptor subunits and associated PSD proteins in schizophrenia in a younger cohort of patients; however, the pattern of changes differs from our findings in elderly patients. We also found evidence of glutamatergic abnormalities in the thalamus in affective disorders, particularly in bipolar disorder.

\section{Glutamatergic Abnormalities in the Thalamus in Schizophrenia}

Several post-mortem studies from our laboratory suggest glutamatergic dysfunction in the thalamus of elderly patients with schizophrenia (Clinton et al, 2003; Ibrahim et al, 2000b; Smith et al, 2001b). We reported reduced expression of NMDA receptor subunit transcripts NR1 and NR2C, and decreased binding at the polyamine and glycine binding sites of the NMDA receptor complex, but did not find prominent changes in the expression of AMPA, kainate, or metabotropic receptors (Ibrahim et al, 2000b; Richardson-Burns et al, 2000). We subsequently reported a significant increase in the transcript expression of three NMDA receptor-associated PSD proteins, NF-L, PSD95, and SAP102; since these molecules are generally thought to promote NMDA receptor function, the expression of these molecules may be elevated in an attempt to compensate for decreased NMDA receptor expression, or in response to a general deficit in thalamic glutamate neurotransmission (Clinton et al, 2003). We have also identified abnormalities of presynaptic vesicular glutamate transporters, which package glutamate for release, and glial-associated excitatory amino transporters that are responsible for removing glutamate from the synaptic cleft, in the thalamus in schizophrenia (Smith et al, 2001a,b). Together these data suggest that glutamate neurotransmission is disturbed in the thalamus in schizophrenia, which may be associated with the structural and metabolic thalamic abnormalities previously reported in the illness (Andreasen, 1997; Jones, 1997).

In the present study, we observed a significant increase of NMDA NR2B subunit transcripts, and decreased NF-L, PSD95 and SAP102 transcripts in the thalamus of younger patients with schizophrenia (mean patient age 43 years). These data conflict with our previous work, which reported decreased NMDA NR1 and NR2C transcipts, and increased NF-L and SAP102 transcripts in a substantially older group of patients (mean patient age of 70 years) (Clinton et al, 2003; Ibrahim et al, 2000b). One possible explanation of these contradictory results could be that different stages of the disease are associated with divergent neurochemical changes. The pattern of gene expression for neurotransmitter receptors and associated molecules may vary depending upon the age of a patient, the types of symptoms (ie positive psychotic symptoms, deficit symptoms, or the extent of cognitive impairment) that predominated, or the length of time that the person suffered from the illness. Data 

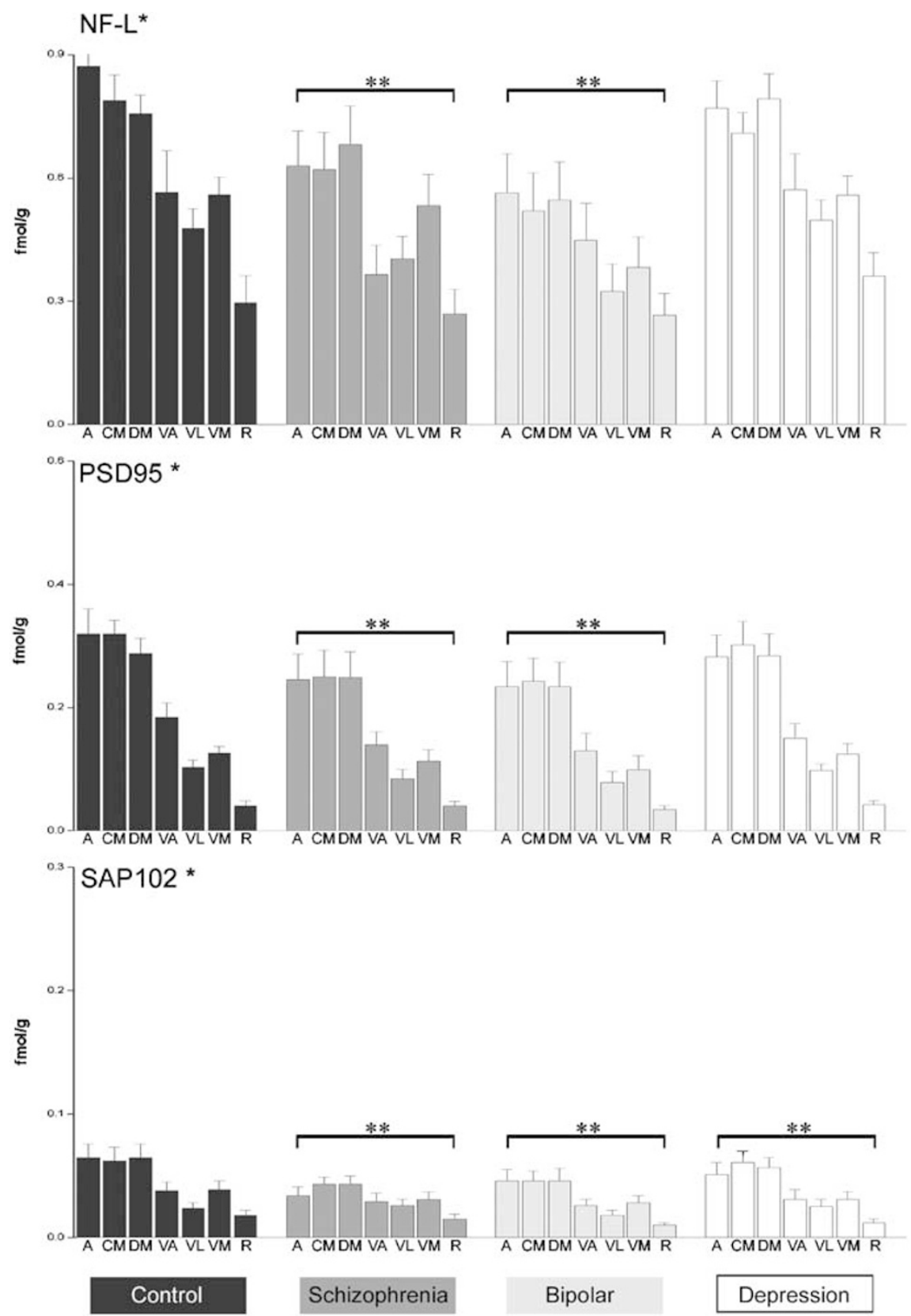

Figure 4 Expression of NMDA receptor subunit transcripts in the thalamus in schizophrenia, bipolar illness, and major depression. NMDA receptor subunit transcripts were measured in seven thalamic nuclei: anterior (A); central medial (CM); dorsomedial (DM); ventral anterior (VA); ventral lateral (VL); ventral medial (VM), and the reticular nucleus (R). Values are mean \pm SEM. *Main effect for diagnosis $(p<0.0 \mathrm{I})$ by two-way ANOVA. ***Post hoc analysis indicated that NF-L and PSD95 expression was significantly reduced in schizophrenia and bipolar illness. SAPI 02 transcripts were significantly reduced in all three illnesses.

from these studies suggest that glutamate neurotransmission is altered both at mid-life and later stages of schizophrenia. It remains unclear, though, whether NMDA receptor-related abnormalities represent a primary problem that interferes with normal thalamic function and contributes to symptoms present during mid-course and late stages of schizophrenia, or if these molecular abnormalities occur secondarily to structural or functional thalamic pathology known to exist in the illness.

NMDA receptors are comprised of at least one NR1 subunit, and a combination of NR2 subunits (A-D). The NR2 subunits are differentially expressed in the brain, and each subtype conveys distinct functional properties to the assembled receptor complex. For instance, the inclusion of different NR2 subunits in vitro can modulate current amplitudes as well as sensitivity to agonists (like glutamate), co-agonists (such as glycine), and NMDA channel blockers, like $\mathrm{Mg}^{2+}$ (Hollmann and Heinemann, 1994). NMDA NR2B subunits are moderately expressed throughout the brain, and in agreement with previous studies, we found moderate levels of NR2B expressed in the thalamus (Ibrahim et al, 2000a, b; Jones et al, 1998). We also detected a significant increase of NR2B transcripts in the thalamus in schizophrenia, which may be functionally significant. Studies 
show that subunit stoichiometry is influenced by neural activity (Audinat et al, 1994), so if glutamate transmission is impaired in the thalamus in schizophrenia, it may lead to increased expression and incorporation of NR2B subunits into existing receptors.

Besides subunit composition, NMDA receptor function is also regulated by interactions between the NMDA subunit C-termini and intracellular scaffolding proteins like PSD95, which serve myriad functions, including targeting the receptors to the synaptic membrane, modulating receptor activity, and coupling receptor activation to intracellular signaling pathways. Furthermore, PSD95-like proteins may physically link NMDA receptors to other effector systems in order to integrate information from multiple neurotransmitter receptors (Sheng and Pak, 2000). In the present study, we found reduced expression of PSD95 and SAP102, which are associated with NMDA NR2 subunits. Decreased expression of these proteins may contribute to a breakdown of glutamate receptor-related intracellular signaling. We also observed decreased expression of NF-L, which has been shown to interact with the NMDA NR1 subunit (Ehlers et al, 1998) and protein phosphatase-1 (PP1), a major protein/ serine/threonine phosphatase that is involved in numerous intracellular processes (Shenolikar, 1994). NF-L may be important for linking NMDA receptors to the synaptic cytoskeleton (Ehlers et al, 1998, 1995) and may influence NMDA receptor signaling by anchoring PP1 at the PSD where it can dephosphorylate various PSD proteins, such as NMDA receptor subunits, or CamKII (Terry-Lorenzo et al, 2000). Although NF-L may participate in or affect NMDA receptor function, its principle function in the neuron is to interact with the other neurofilament subunits (NF-medium and NF-heavy chain) to maintain the neuronal cytoskeleton (Shaw, 1991). Therefore, while reduced NF-L transcript expression may be related to alterations of glutamate and/or NMDA receptor transmission in the thalamus in schizophrenia, it could also be associated with cytoskeletal changes due to thalamic structural pathology in the illness.

\section{Glutamate Abnormalities and Thalamic Dysfunction in Affective Disorders}

The thalamus is a critical link in the corticolimbic circuitry that regulates mood and various cognitive processes, including attention, which can be impaired not only in schizophrenia (Andreasen, 1997), but also in bipolar disorder (Denicoff et al, 1999; Sax et al, 1999) and major depression (Mialet et al, 1996). While there is considerable evidence of thalamic dysfunction in the pathophysiology of schizophrenia, functional or anatomical abnormalities in the thalamus in affective disorders is controversial. A case report in the early 1980s found right thalamic infarction to be associated with secondary mania, suggesting possible thalamic dysfunction in bipolar illness (Bogousslavsky et al, 1988; Cummings and Mendez, 1984). More recent in vivo imaging studies in patients with affective disorder have rendered mixed results. Some studies reported increased thalamic density (Dewan et al, 1988) and volume (Dupont et al, 1995; Strakowski et al, 1999) in bipolar patients, but other work has found that thalamic volume is either unchanged (Dolan et al, 1990; Krishnan et al, 1991, 1993; Sax et al, 1999; Strakowski et al, 1993) or even decreased
(Dasari et al, 1999; Dupont et al, 1995) in bipolar and unipolar depression.

Despite controversial data on possible structural or anatomical abnormalities of the thalamus in bipolar disorder and major depression, there are studies that suggest functional, and possibly neurochemical abnormalities in the thalamus, particularly in bipolar illness. Abnormal blood flow and metabolism have been noted in the medial thalamus in bipolar depression (Buchsbaum et al, 1997; Drevets et al, 1995), and increased levels of creatine were found in the thalamus, which may be related to altered cellular energy metabolism (Deicken et al, 2001). Our data suggest that glutamate neurotransmission may be abnormal in the thalamus of bipolar patients, since we found decreased expression of all three associated PSD proteins examined, NF-L, PSD95, and SAP102. Reduced NF-L transcript expression could be related to thalamic structural pathology in bipolar patients (Soares and Mann, 1997), or may impair NMDA receptor function, as discussed previously. Further, decreased expression of PSD95 and SAP102 in bipolar illness, and decreased SAP102 levels in major depression, may represent a disruption of NMDA receptor-associated signaling and/or the integration of NMDA receptor signals with information from other receptor systems. An earlier study found reduced $[3 \mathrm{H}]$ cyclic AMP (cAMP) dependent protein kinase binding in cytosolic fractions from the thalamus of bipolar patients, which lends support to the possibility of disrupted intracellular signaling in the thalamus in bipolar illness (Rahman et al, 1997).

\section{Limitations of This Study}

Several limitations need to be considered in interpreting data from these studies. First, an important limitation of this and all post-mortem studies in psychiatric illness is the possible confounding effect of psychotropic medications, since these drugs potentially regulate the neurochemical systems under study. The majority of patients with schizophrenia and several of the bipolar patients from this study were exposed to neuroleptics at some point in life (Torrey et al, 2000). Antipsychotic medications can modulate thalamic metabolism and immediate early gene expression (Cohen and Wan, 1996; Deutch et al, 1995; Holcomb et al, 1996). They do not, however, appear to affect thalamic NMDA receptor expression (Ulas et al, 1993). Currently no studies have directly examined the effect of neuroleptics on the expression of NMDA receptor-associated PSD molecules. However, Dracheva et al (2001) reported altered PSD95 and NMDA receptor subunit expression in the prefrontal and occipital corticies in schizophrenia, and found that these transcripts did not differ between patients that were taking antipsychotic medication within 6 weeks of death and those that were medication-free for greater than 6 weeks. Even less is known about the effect of antidepressants and mood stabilizers on the expression of NMDA receptors and associated intracellular molecules. One study showed that antidepressant agents reduce transcript expression for some NMDA receptor subunits in the thalamus, cortex, cerebellum, and striatum of mouse (Boyer et al, 1998). While other work indicates that mood stabilizers like lithium can influence NMDA receptor function (Chuang et al, 2002; Hashimoto 
et al, 2002), no studies to date have examined the effect of these agents on the expression of glutamate receptors.

\section{Conclusions}

Several lines of evidence support a hypothesis of glutamatergic dysfunction in schizophrenia, including our recent reports of altered NMDA receptor subunit and PSD protein transcript expression in the thalamus in schizophrenia (Clinton et al, 2003; Ibrahim et al, 2000b). In the present experiments using a younger patient cohort, although the pattern of changes differs, we have again found evidence of perturbed glutamate neurotransmission in the thalamus in schizophrenia. Further, our data suggest that thalamic glutamate abnormalities may also occur in bipolar disorder. Interestingly, one of the most consistent findings across diagnostic groups was an abnormality of intracellular signaling molecules that are linked to the NMDA receptor, rather than overt changes in the receptor subunits themselves. PSD95 and similar proteins link the NMDA receptor to intracellular enzymes that mediate signaling. Moreover, these molecules may also provide a physical link between different neurotransmitter systems to coordinate and integrate information from multiple effector systems (Sheng and Pak, 2000). Abnormalities of PSD95-like molecules and other intracellular signaling machinery may contribute to dysregulated communication between multiple neurotransmitter systems (such as glutamatergic and dopaminergic systems) that are potentially involved in the neurobiology of schizophrenia and affective disorders.

\section{ACKNOWLEDGEMENTS}

This work was supported by MH53327 (Dr MeadorWoodruff). Post-mortem brains were donated by The Stanley Medical Research Institute's Brain Collection courtesy of Drs Michael B Knable, E Fuller Torrey, Maree J Webster, Serge Weis, and Robert H Yolken. This work was presented at the 41st American College of Neuropsychopharmacology 2002 Annual Meeting, San Juan, Puerto Rico, December 2002.

\section{REFERENCES}

Andreasen NC (1997). The role of the thalamus in schizophrenia. Can J Psychiatry 42: 27-33.

Andreasen NC, Arndt S, Swayze II V, Cizadlo T, Flaum M, O'Leary D et al (1994). Thalamic abnormalities in schizophrenia visualized through magnetic resonance image averaging. Science 266: 294-298.

Audinat E, Lambolez B, Rossier J, Crepel F (1994). Activitydependent regulation of $N$-methyl-D-aspartate receptor subunit expression in rat cerebellar granule cells. Eur J Neurosci 6: $1792-1800$

Bogousslavsky J, Ferrazzini M, Regli F, Assal G, Tanabe H, Delaloye-Bischof A (1988). Manic delirium and frontal-like syndrome with paramedian infarction of the right thalamus. J Neurol Neurosurg Psychiatry 51: 116-119.

Boyer PA, Skolnick P, Fossom LH (1998). Chronic administration of imipramine and citalopram alters the expression of NMDA receptor subunit mRNAs in mouse brain. A quantitative in situ hybridization study. J Mol Neurosci 10: 219-233.
Buchsbaum MS, Someya T, Teng CY, Abel L, Chin S, Najafi A et al (1996). PET and MRI of the thalamus in never-medicated patients with schizophrenia. Am J Psychiatry 153: 191-199.

Buchsbaum M, Someya T, Wu J, Tang CY, Bunney WE (1997). Neuroimaging of bipolar illness with positron emission tomography and magnetic resonance imaging. Psychiatric Ann 27: 489-495.

Byne W, Buchsbaum MS, Kemether E, Hazlett EA, Shinwari A, Mitropoulou V et al (2001). Magnetic resonance imaging of the thalamic mediodorsal nucleus and pulvinar in schizophrenia and schizotypal personality disorder. Arch Gen Psychiatry 58: 133-140.

Chatterton JE, Awobuluyi M, Premkumar LS, Takahashi H, Talantova M, Shin Y et al (2002). Excitatory glycine receptors containing the NR3 family of NMDA receptor subunits. Nature 415: 793-798.

Chuang DM, Chen RW, Chalecka-Franaszek E, Ren M, Hashimoto $\mathrm{R}$, Senatorov V et al (2002). Neuroprotective effects of lithium in cultured cells and animal models of diseases. Bipolar Disord 4: 129-136.

Clinton SM, Haroutunian V, Davis KL, Meador-Woodruff JH (2003). Altered expression of NMDA receptor-associated postsynaptic density proteins in the thalamus in schizophrenia. Am J Psychiatry 160: 1100-1109.

Clinton SM, Meador-Woodruff JH (2002). Nucleus-specific expression of NMDA receptor-associated postsynaptic density proteins in primate thalamus. Thalamus Relat Systems 1: 303-316.

Clinton SM, Meador-Woodruff JH (2003). Thalamic dysfunction in schizophrenia: neurochemical, neuropathological, and in vivo imaging abnormalities. Schizophrenia Res (in press).

Cohen B, Wan W (1996). The thalamus as a site of action of antipsychotic drugs. Am J Psychiatry 153: 104-106.

Coyle JT (1996). The glutamatergic dysfunction hypothesis for schizophrenia. Harvard Rev Psychiatry 3: 241-253.

Cummings JL, Mendez MF (1984). Secondary mania with focal cerebrovascular lesions. Am J Psychiatry 141: 1084-1087.

Das S, Sasaki YF, Rothe T, Premkumar LS, Takasu M, Crandall JE et al (1998). Increased NMDA current and spine density in mice lacking the NMDA receptor subunit NR3A. Nature 393: 377-381.

Dasari M, Friedman L, Jesberger J, Stuve TA, Findling RL, Swales TP et al (1999). A magnetic resonance imaging study of thalamic area in adolescent patients with either schizophrenia or bipolar disorder as compared to healthy controls. Psychiatry Res 91: 155-162.

Deicken RF, Eliaz Y, Feiwell R, Schuff N (2001). Increased thalamic $\mathrm{N}$-acetylaspartate in male patients with familial bipolar I disorder. Psychiatry Res 106: 35-45.

Denicoff KD, Ali SO, Mirsky AF, Smith-Jackson EE, Leverich GS, Duncan CC et al (1999). Relationship between prior course of illness and neuropsychological functioning in patients with bipolar disorder. J Affective Disord 56: 67-73.

Deutch A, Ongur D, Duman R (1995). Antipsychotic drugs induce Fos protein in the thalamic paraventricular nucleus: a novel antipsychotic drug action. Neuroscience 66: 337-346.

Dewan MJ, Haldipur CV, Lane EE, Ispahani A, Boucher MF, Major LF (1988). Bipolar affective disorder. I. Comprehensive quantitative computed tomography. Acta Psychiatr Scand 77: 670-676.

Dolan RJ, Poynton AM, Bridges PK, Trimble MR (1990). Altered magnetic resonance white-matter T1 values in patients with affective disorder. Br J Psychiatry 157: 107-110.

Dracheva S, Marras SAE, Elhakem SL, Kramer FR, Davis KL, Haroutunian V (2001). N-methyl-D-aspartic acid receptor expression in the dorsolateral prefrontal cortex of elderly patients with schizophrenia. Am J Psychiatry 158: 1400-1410.

Drevets WC, Spitznagel E, Raichle ME (1995). Functional anatomical differences between major depressive subtypes. J Cereb Blood Flow Metab 15: S93. 
Dupont RM, Jernigan TL, Heindel W, Butters N, Shafer K, Wilson T et al (1995). Magnetic resonance imaging and mood disorders. Localization of white matter and other subcortical abnormalities. Arch Gen Psychiatry 52: 747-755.

Ehlers M, Fung E, O’Brien R, Huganir R (1998). Splice variantspecific interaction of the NMDA receptor subunit NR1 with neuronal intermediate filaments. J Neurosci 18: 720-730.

Ehlers MD, Tingley WG, Huganir RL (1995). Regulated subcellular distribution of the NR1 subunit of the NMDA receptor. Science 269: 1734-1737.

Gao XM, Sakai K, Roberts RC, Conley RR, Dean B, Tamminga CA (2000). Ionotropic glutamate receptors and expression of $\mathrm{N}$ methyl-D-aspartate receptor subunits in subregions of human hippocampus: effects of schizophrenia. Am J Psychiatry 157: 1141-1149.

Gilbert AR, Rosenberg DR, Harenski K, Spencer S, Sweeney JA, Keshavan MS (2001). Thalamic volumes in patients with firstepisode schizophrenia. Am J Psychiatry 158: 618-624.

Goff D, Berman I, Posever T, Herz L, Leahy L, Lynch G (1999). A preliminary dose escalation trial of CX516 (Ampakine) added to clozapine in schizophrenia. Schizophrenia Res 36: 280.

Goff DC, Coyle JT (2001). The emerging role of glutamate in the pathophysiology and treatment of schizophrenia. Am J Psychiatry 158: 1367-1377.

Goff DC, Tsai G, Manoach DS, Coyle JT (1995). Dose-finding trial of D-cycloserine added to neuroleptics for negative symptoms in schizophrenia. Am J Psychiatry 152: 1213-1215.

Goff DC, Wine L (1997). Glutamate in schizophrenia: clinical and research implications. Schizophrenia Res 27: 157-168.

Hashimoto R, Hough C, Nakazawa T, Yamamoto T, Chuang DM (2002). Lithium protection against glutamate excitotoxicity in rat cerebral cortical neurons: involvement of NMDA receptor inhibition possibly by decreasing NR2B tyrosine phosphorylation. J Neurochem 80: 589-597.

Hazlett EA, Buchsbaum MS, Byne W, Wei TC, Spiegel-Cohen J, Geneve C et al (1999). Three-dimensional analysis with MRI and PET of the size, shape, and function of the thalamus in the schizophrenia spectrum. Am J Psychiatry 156: 1190-1199.

Holcomb H, Cascella N, Thaker G, Medoff D, Dannals R, Tamminga C (1996). Funcitonal sites of neuroleptic drug action in the human brain: PET/FDG studies with and without haloperidol. Am J Psychiatry 153: 41-49.

Hollmann M, Heinemann S (1994). Cloned glutamate receptors. Annu Rev Neurosci 17: 31-108.

Ibrahim H, Healy D, Hogg AJ, Meador-Woodruff J (2000a). Nucleus-specific expression of ionotropic glutamate receptor subunit mRNAs and binding sites in primate thalamus. $\mathrm{Mol}$ Brain Res 79: 1-17.

Ibrahim HM, Hogg AJ, Healy DJ, Haroutunian V, Davis KL, Meador-Woodruff JH (2000b). Ionotropic glutamate receptor binding and subunit mRNA expression in thalamic nuclei in schizophrenia. Am J Psychiatry 157: 1811-1823.

Javitt D, Zylberman I, Zukin S, Heresco-Levy U, Lindenmayer J (1994). Amelioration of negative symptoms in schizophrenia by glycine. Am J Psychiatry 151: 1234-1336.

Jones EG (1997). Cortical development and thalamic pathology in schizophrenia. Schizophrenia Bull 23: 483-501.

Jones EG (1998). The thalamus of primates. In: Bloom FE, Bjorklund A, Hokfelt T (eds). The Primate Nervous System, Part II, Vol 14, New York: Elsevier. pp 1-246.

Jones EG, Tighilet B, Tran BV, Huntsman MM (1998). Nucleusand cell-specific expression of NMDA and non-NMDA receptor subunits in monkey thalamus. J Comp Neurol 397: 371-393.

Krishnan KR, Doraiswamy PM, Figiel GS, Husain MM, Shah SA, $\mathrm{Na} C$ et al (1991). Hippocampal abnormalities in depression. J Neuropsychiatry Clin Neurosci 3: 387-391.

Krishnan KR, McDonald WM, Doraiswamy PM, Tupler LA, Husain M, Boyko OB et al (1993). Neuroanatomical substrates of depression in the elderly. Eur Arch Psychiatry Clin Neurosci 243: 41-46.

Lahti A, Holcomb H, Medoff D, Tamminga C (1995). Ketamine activates psychosis and alters limbic blood flow in schizophrenia. Neuroreport 6: 869-872.

Mialet JP, Pope HG, Yurgelun-Todd D (1996). Impaired attention in depressive states: a non-specific deficit? Psychol Med 26: 1009-1020.

Miller JA (1991). The calibration of 35S or 32P with 14C-labeled brain paste or $14 \mathrm{C}$-plastic standards for quantitative autoradiography using LKB Ultrofilm or Amersham Hyperfilm. Neurosci Lett 121: 211-214.

Oke AF, Adams RN (1987). Elevated thalamic dopamine: possible link to sensory dysfunctions in schizophrenia. Schizophrenia Bull 13: 589-604.

Olney JW, Newcomer JW, Farber NB (1999). NMDA receptor hypofunction model of schizophrenia. J Psychiatric Res 33: 523-533.

Pakkenberg B (1990). Pronounced reduction of total neuron number in mediodorsal thalamic nucleus and nucleus accumbens in schizophrenics. Arch Gen Psychiatry 47: 1023-1028.

Popken GJ, Bunney Jr WE, Potkin SG, Jones EG (2000). Subnucleus-specific loss of neurons in medial thalamus of schizophrenics. Proc Natl Acad Sci USA 97: 9276-9280.

Rahman S, Li PP, Young LT, Kofman O, Kish SJ, Warsh JJ (1997). Reduced [3H]cyclic AMP binding in postmortem brain from subjects with bipolar affective disorder. J Neurochem 68: 297-304.

Richardson-Burns SM, Haroutunian V, Davis KL, Watson SJ, Meador-Woodruff JH (2000). Metabotropic glutamate receptor mRNA expression in the schizophrenic thalamus. Biol Psychiatry 47: 22-28.

Sax KW, Strakowski SM, Zimmerman ME, DelBello MP, Keck Jr PE, Hawkins JM (1999). Frontosubcortical neuroanatomy and the continuous performance test in mania. Am J Psychiatry 156: 139-141.

Shaw G (1991). Neurofilament proteins. In: Burgoyne RD (ed). The Neuronal Cytoskeleton. New York: Wiley-Liss Inc. pp 621-635.

Sheng M (2001). The postsynaptic NMDA-receptor-PSD-95 signaling complex in excitatory synapses of the brain. J Cell Sci 114: 1251.

Sheng M, Pak D (2000). Ligand-gated ion channel interactions with cytoskeletal and signaling proteins. Annu Rev Physiol 62: 755-778.

Shenolikar S (1994). Protein serine/threonine phosphatases-new avenues for cell regulation. Ann Rev Cell Biol 10: 55-86.

Silbersweig DA, Stern E, Frith C, Cahill C, Holmes A, Grootoonk S et al (1995). A functional neuroanatomy of hallucinations in schizophrenia. Nature 378: 176-179.

Smith RE, Haroutunian V, Davis KL, Meador-Woodruff JH (2001a). Expression of excitatory amino acid transporter transcripts in the thalamus of subjects with schizophrenia. Am J Psychiatry 158: 1393-1399.

Smith RE, Haroutunian V, Davis KL, Meador-Woodruff JH (2001b). Vesicular glutamate transporter transcript expression in the thalamus in schizophrenia. Neuroreport 12: 2885-2887.

Soares JC, Mann JJ (1997). The anatomy of mood disordersreview of structural neuroimaging studies. Biol Psychiatry 41: 86-106.

Strakowski SM, DelBello MP, Sax KW, Zimmerman ME, Shear PK, Hawkins JM et al (1999). Brain magnetic resonance imaging of structural abnormalities in bipolar disorder. Arch Gen Psychiatry 56: $254-260$.

Strakowski SM, Wilson DR, Tohen M, Woods BT, Douglass AW, Stoll AL (1993). Structural brain abnormalities in first-episode mania. Biol Psychiatry 33: 602-609.

Tamminga CA, Thaker GK, Buchanan R, Kirkpatrick B, Alphs LD, Chase TN et al (1992). Limbic system abnormalities identified in schizophrenia using positron emission tomography with 
fluorodeoxyglucose and neocortical alterations with deficit syndrome. Arch Gen Psychiatry 49: 522-530.

Terry-Lorenzo R, Inoue M, Connor J, Haystead T, Armbruster B, Gupta $\mathrm{R}$ et al (2000). Neurofilament-L is a protein phosphatase1-binding protein associated with neuronal plasma membrane and post-synaptic density. J Biol Chem 275: 2139-2446.
Torrey EF, Webster M, Knable M, Johnston N, Yolken RH (2000). The Stanley foundation brain collection and neuropathology consortium. Schizophrenia Res 44: 151-155.

Ulas J, Nguyen L, Cotman CW (1993). Chronic haloperidol treatment enhances binding to NMDA receptors in rat cortex. Neuroreport 4: 1049-1051. 